\title{
Clinical-epidemiological profile of children and adolescents with COVID-19 in Ceará
}

Ana Nery Melo Cavalcante 1

iD https://orcid.org/0000-0002-3830-7767

Lohanna Valeska de Sousa Tavares 2

iD https://orcid.org/0000-0002-6426-0755

Maria Luiza Almeida Bastos 3

iD https://orcid.org/0000-0003-2427-5896

Rosa Lívia Freitas de Almeida 4

iD https://orcid.org/0000-0001-6423-543X

\footnotetext{
1,4 Programa de Pós-graduação em Saúde Coletiva. Universidade de Fortaleza. Fortaleza, CE, Brasil. Av. Washington Soares, 1321. Edson Queiroz. Fortaleza, CE, Brasil. CEP: 60.811-905. E-mail: ananery.melo@bol.com.br

2 Hospital São José de doenças infecciosas. Fortaleza, CE, Brasil.

3 Universidade Federal do Ceará. Fortaleza, CE, Brasil.
}

\begin{abstract}
Objectives: to describe the clinical-epidemiological profile of children and adolescents notified by COVID-19 in Ceará.

Methods: descriptive epidemiological study from open data repositories of the State Government of Ceará, about cases of OVID-19 in children and adolescents, from 03/15/2020 to 07/31/2020. For data analysis the tests $\chi^{2}$ Pearson, Fisher's exact and Poisson's regression with robust variance were used.

Results: 48,002 cases of children and adolescents suspected of COVID-19 were reported, of which 18,180 (8.9\%) were confirmed. The median of confirmed cases was 12 years old, $10.5 \%$ were newborns/lactants, $10.7 \%$ were pre-school children, $21.2 \%$ were school children and $57.7 \%$ were adolescents. They evolved to death $0.3 \%$ of the cases, of which $15 \%$ had comorbidities. They needed hospitalization $1.8 \%$ of the cases. The highest probability of hospitalization was found in newborns/lactants, male and with comorbidities.

Conclusions: most of the confirmed cases occurred in adolescents, however, the evolution of the disease was more severe and with greater need for hospitalization in the age group of newborns/lactants, being the male gender and the presence of comorbidities additional factors for the need for hospitalization.

Key words Pandemics, SARS-CoV-2, Health profile, Pediatrics
\end{abstract}

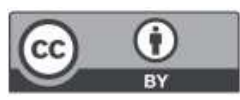




\section{Introduction}

COVID-19 is an acute infectious disease caused by a coronavirus identified for the first time in December 2019, and named SARS-CoV-2 (Severe acute respiratory syndrome Coronavirus 2). This virus appeared in Wuhan, China, and quickly disseminated for all over the world, causing a deep global impact, with rising rates of hospitalization and lethality. 1

The COVID-19 pandemic, declared in March 11, 2020 by the World Health Organization (WHO), lead many countries to adopt unprecedented public health measures, in attempt to hold the spread of the virus. ${ }^{2}$ Despite that, until September 19, 30,543,040 cases of the disease were confirmed in the world. ${ }^{3}$

In Brazil, during the period between February to September 19, 2020, 4,582,240 cases and 136,532 deaths were confirmed, whereas the State of Ceará had 234,551 confirmed cases and 8,867 deaths by due to COVID-19 in the same period. 4

Among diagnosed cases of COVID-19, children and adolescents correspond to the less affected age range. Besides that, around $90 \%$ of them are asymptomatic, and, among those who portray symptoms, these are far less severe compared to adults. 5 Although, children and adolescents with associated comorbidities, such as congenital heart and pulmonary diseases, are in greater risk of developing severe COVID-19.6,7

The most common symptoms in pediatric age range are similar to acute respiratory infections, such as fever, cough, sore throat, sneezing, myalgia and fatigue. Symptoms of gastrointestinal tract, such as vomiting, diarrhea and abdominal pain were also observed. Respiratory distress or pulmonary insufficiency are indicators of severity, as well as signs of shock and oxygen saturation under $95 \% .8,9$

In the literature, $7,10,11$ some hypotheses were raised in order to justify why children infected with SARS-CoV-2 presented less severe cases: 1 . The immune system of children is immature in face of infections by other viruses of the respiratory tract (Respiratory syncytial virus or influenza), producing less pro-inflammatory cytokines and being a protective factor against SARS-CoV-2;2. Due to previous contact with other common coronaviruses, children develop preexisting immunity and cross-reactive antibodies to SARS-CoV-2, which can represent a protective role; 3 . Children have greater bacterial and viral colonization of mucosal surfaces, which may limit colonization and growing of SARS-CoV-2 by means of microbial competition; 4 . Children have less receptors of angiotensin-converting enzyme 2 (ACE 2), receptors of SARS-CoV-2, and less affinity compared to adults, being able, thus, of being less affected by COVID-19; 5 . It is less prevalent within children the presence of comorbidities associated with severe diseases.

Most children and adolescents are infected by contact with an adult at home, once since the onset of pandemic, schools were closed and children stood at home, with their families, in social isolation. According to a study conducted in China, which assessed 74 children with COVID-19, 95.6\% of infected children had contact at home with adults with the disease, almost the half presented co-infection with other respiratory pathogens and all of them were discharged from hospital. 12

Given the above, this study aimed to describe the clinical-epidemiological profile of children and adolescents notified by COVID-19 in State of Ceará.

\section{Methods}

Cross-sectional, epidemiological and descriptive research, assessed the five first months of COVID19 prevalence in State of Ceará, in the period between March 15 and July 13, 2020. The study population was composed by children $(<1$ year to 9 years) and adolescents (10 to 19 years), according to World Health Organization (WHO). ${ }^{13}$ The data on notification of cases and results of exams were obtained from open data repository of the State of Ceará Government. 14 The identification of patients was used for deterministic linkage between notification registries and results of exams. The notifications that presented negative or positive results of COVID-19 diagnosis were stratified according to the levels of pediatric age (neonatal and lactating - 0 to 1 year, preschool -2 to 4 years, school -5 to 9 years, adolescent -10 to 19 years), adult (20 to 59 years) and elderly (over 60 years). The cases in children and adolescents were analyzed according type of diagnosis confirmation (immunology tests, molecular biology, clinical-image and clinical-epidemiological criteria), sex, age, hospitalization, comorbidities, hospitalization in ICU and death.

Counting data were expressed as cases, percentages, and presented with confidence interval for the proportions of their categories; Pearson's chi squared test or, when necessary, Fisher's exact test were used for the analysis. Numerical data were expressed as mean and standard deviation (SD) and in the absence of normal distribution, as median and $25^{\circ}-75^{\circ}$ interquartile interval; the normality of data distribution was evaluated with the KolmogorovSmirnov test. For confirmed cases of COVID-19 in children and adolescents, they were estimated 
through Poisson regression with robust variance, 15 the probability of hospitalization according to the variables sex, age, death and presence of comorbidities, being the results expressed in prevalence ratios (PR) and their 95\% confidence interval. In all analyzes, the $p<0.05$ value was reference for indicating statistical significance. Besides, the entire study was developed using resources of the SPSS version 25 software.

\section{Results}

Ceará was the first state of Brazilian Northeast to notify COVID-19 cases, in March 15, and until July 31,2020 , there were 531,877 notified cases of the disease, of which, 494,025 (91\%) referred to diagnostic conclusion, and, of these, 202,751 (41.9\%) were confirmed positive for COVID-19. Of the reported cases with diagnosis information, 48,002 (9.9\%) were children and adolescents aged 0-19 years old, being 18,180 (8.9\%) positive for COVID19 (Table 1).

In relation to the diagnosis method used for confirming cases in children and adolescents, 15,683 $(86.3 \%)$ were by means of immunology tests: Quick test, ELISA, Electrochemiluminescence (ECL), Chemiluminescence (CL); 2,231 (12.3\%) by molecular biology test (RT-PCR) and $266(1.5 \%)$ by clinical-epidemiological criteria or clinical-image criteria.

The median age for children and adolescents diagnosed with COVID-19 was 12 years (IRQ= 5$17)$ and, in relation to age range, $1,900(0.9 \%)$ were lactating newborns, $1,938(1,0 \%)$ were preschool children (2 to 4 years), 3,853 (1.9\%) school children (5 to 9 years) and 10,489 (5.2\%) adolescents with 10 to 19 years. Besides that, it was observed a higher proportion of the female gender 9,536 (52.4\%; $\mathrm{CI} 95 \%=51.7-53.2)$ with statistic significance (CImasc: 46.8 - 48.3) (Tables 2 and 3)

Information on comorbidities were registered in $53(0.3 \%)$ cases, 11 children presented more than one variety, resulting in 64 comorbidities, according to the description: neurological alterations in 21 $(0.12 \%)$, asthma in $16(0.08 \%)$, immunodeficiency in $6(0.03 \%)$, cardiovascular disease in $5(0.03 \%)$, Down syndrome in $4(0.02 \%)$, pneumopathy in 4 $(0.02 \%)$, diabetes in $3(0.02 \%)$, kidney disease in 3 $(0.02 \%)$, hematological disease in $1(0.01 \%)$ and obesity in $1(0.01 \%)$.

$60(0.3 \%)$ children and adolescents had death outcomes, being $30(0.3 \%)$ adolescents, $20(1.1 \%)$ lactating-NB, $5(0.3 \%)$ preschool children and 5 $(0.1 \%)$ schoolchildren. In relation to adult age range,
$1,770(1.2 \%)$ deaths and in elderly, $6,530915.6 \%)$. 8,360 deaths were registered in general population, with a lethality percentage of $4.1 \%$, being 13.7 times higher than that observed in children and adolescents.

$319(1.8 \%)$ hospitalization occurrences were registered in children and adolescents with confirmed COVID-19, and of these, 58 (18.1\%) used Intensive Care Unit (ICU), of which, 10 (17.2\%) presented comorbidities and 20 (34.5\%) evolved to death during hospitalization in intensive care units. The median of time between hospitalization and onset of symptoms was 8 days $($ IRQ $=4-11)($ Table 3).

In the univariate analysis, the factors associated with hospitalization were age, sex, comorbidities and death. The lactating/NB children and preschool children presented higher probability of hospitalization compared to adolescents $\mathrm{PR}=5.1(\mathrm{CI} 95 \%=3.9-6.6)$; $\mathrm{PR}=2.1(\mathrm{CI} 95 \%=1.5-2.9)$, respectively. The probability of hospitalization was $40 \%$ higher for the male sex $\mathrm{PR}=1.4(1.1-1.8)$ and presenting any comorbidity increased 57 times the probability of hospitalization (Table 4). The median age of 60 cases of confirmed death by COVID-19 in children was 10 years (IRQ under 1 year to 16 years); 32 (53.3\%) of them were male and $9(15 \%)$ had comorbidities, being $6(10 \%)$ cases of neurological disease, 2 (3.3\%) Down syndrome and 1 (1.6\%) immunodeficiency.

\section{Discussion}

In the present study, we evaluated the profile of children and adolescents with COVID-19, becoming evident that this population was less affected and had better evolution compared to adults. Three possibilities can justify this outcome: 1 . Since the onset of the pandemic, in Ceará, the school classes were suspended, diminishing the contact between children and contactants with COVID-19; 2 . According to the literature, most children with COVID-19 are asymptomatic, do not search for medical care and, thus, are not diagnosed6; 3. Children have COVID-19 protective immune system, besides presenting less comorbidities in relation to adults and elderly. 10

According to systematic review published in June, 2020, around 1 to $5 \%$ of diagnosed cases with COVID-19 occurred in the pediatric age range. 5 The Korean Disease Control and Prevention Agency reported that, until March 20, 2020, 6.3\% of all confirmed cases of COVID-19 were patients under 19 years old.11 In the State of Ceará, $8.9 \%$ of children and adolescents aged 0 to 20 incomplete years 
Table 1

Reported and confirmed cases of COVID-19, according to age range. Ceará, March 15 to July 31, 2020.

\begin{tabular}{|c|c|c|c|c|c|c|}
\hline \multirow[t]{2}{*}{ Age range } & \multicolumn{3}{|c|}{$\begin{array}{c}\text { Confirmed } \\
(\mathrm{N}=202.751)^{* *}\end{array}$} & \multicolumn{2}{|c|}{$\begin{array}{l}\text { Reported }^{*} \\
(\mathrm{~N}=484.025)\end{array}$} & \\
\hline & $\mathrm{n}$ & $\%$ & $\mathrm{Cl} 95 \%$ & $\mathrm{n}$ & $\%$ & $\mathrm{Cl} 95 \%$ \\
\hline Children/Adolescent & 18,180 & 8.9 & $8.8-9.1$ & 48.002 & 9.9 & $8.8-10.1$ \\
\hline Adult & 142,747 & 70.4 & $70.2-70.6$ & 351.804 & 72.7 & $72.6-72.8$ \\
\hline Elderly & 41,824 & 20.6 & $20.5-20.8$ & 84.219 & 17.4 & $17.3-17.5$ \\
\hline
\end{tabular}

* Reported with diagnostic results. * * Percentage calculated in relation to reported cases; NB=Newborn. Source: Integrasus Ceará, 2020.

Table 2

Epidemiological characteristics of COVID-19 cases in children and adolescents. Ceará, March 15 to July $31,2020$.

\begin{tabular}{|c|c|c|c|}
\hline Variables & $N=18,180$ & $\%$ & $\mathrm{Cl} 95 \%$ \\
\hline \multicolumn{4}{|l|}{ Sex } \\
\hline Male & 8,644 & 47.6 & $46.8-48.3$ \\
\hline Female & 9,536 & 52.4 & $51.7-53.2$ \\
\hline \multicolumn{4}{|l|}{ Age (years) } \\
\hline Age $P_{50}\left(P_{25}-P_{75}\right)$ & $12(6-17)$ & & \\
\hline \multicolumn{4}{|l|}{ Age range } \\
\hline Lactating & 1,900 & 10.5 & $10-10.9$ \\
\hline Preschool & 1,938 & 10.7 & $10.2-11.1$ \\
\hline School & 3,853 & 21.2 & $20.6-21.8$ \\
\hline Adolescent & 10,489 & 57.7 & $57-58.4$ \\
\hline \multicolumn{4}{|l|}{ Type of tests } \\
\hline Molecular & 2,231 & 12.3 & $11.8-12.8$ \\
\hline Immunology & 15,683 & 86.3 & $85.8-86.8$ \\
\hline Clinical/image & 266 & 1.5 & $1.3-1.6$ \\
\hline \multicolumn{4}{|l|}{ Comorbidities } \\
\hline No & 18,127 & 99.7 & $99.6-99.8$ \\
\hline Yes & 53 & 0.3 & $0.2-0.4$ \\
\hline \multicolumn{4}{|l|}{ Hospitalization } \\
\hline No & 17,861 & 98.2 & $98-98.4$ \\
\hline Yes & 319 & 1.8 & $1.6-2$ \\
\hline \multicolumn{4}{|c|}{ Time between hospitalization and symptoms (days) } \\
\hline Time $P_{50}\left(P_{25}-P_{75}\right)$ & $8(4-11)$ & & \\
\hline \multicolumn{4}{|l|}{ Hospitalization in ICU } \\
\hline No & 18,122 & 99.7 & $99.6-99.8$ \\
\hline Yes & 58 & 0.3 & $0.2-0.4$ \\
\hline \multicolumn{4}{|l|}{ Deaths } \\
\hline No & 18,120 & 99.7 & $99.6-99.7$ \\
\hline Yes & 60 & 0.3 & $0.3-0.4$ \\
\hline
\end{tabular}

$\mathrm{ICU}=$ Intensive Care Unit.

Source: Integrasus Ceará, 2020. 
Hospitalization in ICU of confirmed COVID-19 cases between children and adolescents according to age range. Ceará, March 16 to July 3 , 2020.

\begin{tabular}{|c|c|c|c|c|c|c|c|c|c|c|c|c|c|c|}
\hline \multirow[t]{2}{*}{ Age range } & \multicolumn{2}{|c|}{$\begin{array}{l}\text { Confirmed } \\
(\mathrm{N}=18,180)\end{array}$} & \multicolumn{3}{|c|}{$\begin{array}{l}\text { Hospitalization } \\
\qquad(\mathrm{N}=319)\end{array}$} & \multicolumn{3}{|c|}{$\begin{array}{c}\text { ICU } \\
(\mathrm{N}=58)\end{array}$} & \multicolumn{3}{|c|}{$\begin{array}{l}\text { Death } \\
(\mathrm{N}=60)\end{array}$} & \multicolumn{3}{|c|}{$\begin{array}{l}\text { Comorbidities } \\
\qquad(\mathrm{N}=64)\end{array}$} \\
\hline & $\mathrm{n}$ & $\%$ & $\mathrm{n}$ & $\%$ & IC95\% & $\mathrm{n}$ & $\%$ & IC95\% & $\mathrm{n}$ & $\%$ & IC95\% & $\mathrm{n}$ & $\%$ & IC95\% \\
\hline Lactating/NB & 1,900 & 10.5 & 106 & 5.6 & $4.6-6.7$ & 19 & 1.0 & $0.6-1.5$ & 20 & 1.1 & $0.7-1.6$ & 13 & 0.6 & $0.3-1$ \\
\hline Preschool & 1,938 & 10.7 & 44 & 2.3 & $1.7-3.0$ & 5 & 0.3 & $0.1-0.6$ & 5 & 0.3 & $0.1-0.6$ & 11 & 0.5 & $0.2-0.8$ \\
\hline School & 3,853 & 21.2 & 54 & 1.4 & $1.1-1.8$ & 5 & 0.1 & $0-0.3$ & 5 & 0.1 & $0-0.3$ & 16 & 0.4 & $0.2-0.6$ \\
\hline Adolescent & 10,489 & 57.7 & 115 & 1.1 & $0.9-1.3$ & 29 & 0.3 & $0.2-0.4$ & 30 & 0.3 & $0.2-0.4$ & 24 & 0.2 & $0.1-0.3$ \\
\hline
\end{tabular}

$\mathrm{NB}=$ Newborn; ICU = Intensive Care Unit.

Source: Integrasus Ceará, 2020.

Table 4

Factors associated with the probability of hospitalization in children and adolescents diagnosed with COVID-19.Ceará, March 15 to July 31, 2020.

\begin{tabular}{|c|c|c|c|c|c|c|c|}
\hline \multirow[t]{2}{*}{ Variables } & \multirow{2}{*}{$\begin{array}{c}\text { Cases } \\
(\mathrm{N}=18,180)\end{array}$} & \multicolumn{6}{|c|}{ Hospitalization $(\mathrm{N}=319)$} \\
\hline & & $\mathrm{n}$ & $\%$ & $\mathrm{Cl} 95 \%$ & $p$ & PR & $\mathrm{Cl} 195 \%$ \\
\hline \multicolumn{8}{|l|}{ Age } \\
\hline Lactating/NB & 1,900 & 106 & 5.6 & $4.6-6.7$ & & 5.1 & $3.9-6.6$ \\
\hline Preschool & 1,938 & 44 & 2.3 & $1.7-3.0$ & $<0.001$ & 2.1 & $1.5-2.9$ \\
\hline School & 3,853 & 54 & 1.4 & $1.1-1.8$ & & 1.3 & $0.9-1.8$ \\
\hline Adolescent & 10,489 & 115 & 31.1 & $0.9-1.3$ & & 1 & \\
\hline \multicolumn{8}{|l|}{ Sex } \\
\hline Male & 8,644 & 179 & 2.1 & $1.8-2.4$ & 0.002 & 1.4 & $1.1-1.8$ \\
\hline Female & 9,536 & 140 & 1.5 & $1.2-1.7$ & & 1 & \\
\hline \multicolumn{8}{|l|}{ Comorbidities } \\
\hline No & 18,127 & 273 & 1.5 & $1.3-1.7$ & & 1 & \\
\hline Yes & 53 & 46 & 86.8 & $74.8-93.6$ & $<0.001$ & 57.6 & $49.2-78.8$ \\
\hline \multicolumn{8}{|l|}{ Death } \\
\hline No & 18,120 & 279 & 1.5 & $1.4-1.7$ & & 1 & \\
\hline Yes & 60 & 40 & 66.7 & $54.2-77.6$ & $<0.001$ & 43.2 & $31.1-60.3$ \\
\hline
\end{tabular}

$\mathrm{NB}=$ Newborn; $\mathrm{PR}=$ Prevalence ratio ${ }^{*} p=$ Pearson's chi squared

Source: Integrasus Ceará, 2020.

had confirmed infection with COVID-19, a higher percentage than those found in other studies.5,11 It is yet admitted that sub-diagnosis in this age range impairs a real estimate of the local epidemiological panorama of the disease. Due to being asymptomatic or oligosymptomatic, the majority do not need medical care, and do not execute diagnosis of the disease, which is reserved for cases with more severe and/or rampant cases.

A cohort study that assessed 2,143 patients with less than 19 years with suspect or confirmed COVID-19 obtained mean age of seven years, without differentiation regarding gender, and the most severe cases occurred with newborn children and preschool children. 8 The median age found in this study, - 12 years - was higher when compared to that of 6.7 years found in a recent systematic review, 5 presenting higher proportion of positive cases for female gender; although for cases that needed hospitalization, male gender showed a $40 \%$ higher probability than female gender.

Of the children hospitalized, $18.1 \%$ needed treatment in ICUs, of which $17.2 \%$ presented some comorbidity. The age range of lactating/NB 
presented higher percentage of hospitalization (5.6\%). A multicentric pediatric cohort study from Europe that enrolled 82 institutions found a rate of $8 \%$ in ICU hospitalization, with 5 times more chances of a child be under one month of life, with lethality rate of $8.3 \%$, of which $50 \%$ had preexisting diseases. Besides, $25 \%$ of children diagnosed with COVID-19 had comorbidities, of which the most common were: chronic pulmonary disease (asthma and bronchopulmonary dysplasia), followed by cancer (leukemia, lymphoma and solid tumors), neurological disorders (epilepsy and cerebral palsy), congenital heart disease, chromosomal abnormalities (trisomy of chromosome 21) and chronic kidney disease. 16

The lethality rate for children diagnosed with COVID-19 that needed hospitalization in ICUs was $34.5 \%$, higher than what was found in global literature. According to a study carried out in Paris, 27 children that had severe forms of COVID-19 had this percentage at $18.5 \% .17$ The highest lethality rate found in Ceará, apart from being intimately related to sub-notification of cases, may also indicate the consequence of delayed search for healthcare, postponing initial intensive measures, which would avoid the lethal outcome.

The estimate lethality in a study that evaluated 72,314 Chinese patients was $0 \%$ in the age range of 0 to 9 years and $0.18 \%$ in 10 to 19 years, whilst overall lethality was $2.3 \%$ and $8 \%$ in the age range of $70-79$ years. 18 In this study, the lethality found in patients with 0 to 19 years was $0.3 \%$ and the global lethality, $4.1 \%$ in Ceará, however, being always necessary to consider sub-diagnosing, causing a overestimation of the current epidemiological rates.

Once information for this study was obtained

\section{References}

1. Safadi MAP. The intriguing features of COVID-19 in children and its impact on the pandemic. J Pediatr. 2020; 96 (3) 265-8.

2. WHO (World Health Organization). Surto de doença por coronavírus (COVID-19) [online]. [Acesso em 15 de maio de 2020]. Disponível em:https://www.who.int/emergencies/diseases/novel-coronavirus-2019

3. Boletim Epidemiológico Especial N32. Doença pelo Coronavírus COVID-19. Brasília, DF: Ministério da Saúde; 2020. [acesso 23 set 2020]. Disponível em: https://www.gov.br/saude/pt-br/Coronavirus/boletinsepidemiologicos- $1 /$ set/boletim-epidemiologico-covid-32final-23-09_18h30.pdf

4. Boletim Epidemiológico N44. Doença pelo Coronavírus COVID-19. Fortaleza, CE: Secretaria de Saúde do Estado from a database for epidemiological and sanitary control and strategic health planning, some of the variables were ignored, impairing the reliability of data interpretation.

Most confirmed cases occurred with adolescents. However, the evolution of the disease was more severe and with more necessity of hospitalization in the age group of lactating/NB, being male gender and presence of comorbidities additional factors for the necessity of hospitalization. In this study, the clinical course of COVID-19 in Ceará in children and adolescents was milder than in adults, agreeing with the global literature. The proportion of deaths in children hospitalized in ICUs was higher than what is described in the literature. The studies about clinical, laboratorial and therapeutic findings in pediatric age range are scarce, and they are necessary in order to increase the knowledge about the disease, and consequently, for the appropriate management in this age range.

\section{Author's contribution}

Cavalcante ANM worked in the conception, critical review of the content and statistical analysis. Tavares LVS contributed to the investigation of data. Bastos MLA contributed to the discussion of findings. Almeida RLF was responsible for the conception and definition of the theme, data organization, methodological design and statistical analysis. All authors contributed with the planning, data analysis and writing of the manuscript and approved the final version of the article. do Ceará; 2020. [acesso 23 set 2020]. Disponível em: $<$ https://coronavirus.ceara.gov.br/project/boletimepidemiologico-no-44-de-24-de-setembro-de-2020/>

5. Ludvigsson JF. Systematic review of COVID-19 in children shows milder cases and a better prognosis than adults. Acta Paediatr. 2020; 109 (6): 1088-95.

6. She J, Liu L, Liu W. COVID-19 epidemic: Disease characteristics in children. J MedVirol. 2020;92(7):747-54.

7. Dhochak N, Singhal T, Kabra SK, Lodha R. Pathophysiology of COVID-19: Why children fare better than adults? Indian J Pediatr. 2020; 416.

8. Dong Y, Mo X, Hu Y, Qi X, Jiang F, Jiang Z, Tong S. Epidemiology of COVID-19 among children in China. Pediatrics. 2020; 145 (6). 
9. Brasil. Conselho Nacional de Secretarias Municipais de Saúde - CONASEMS. Conselho Nacional de Secretários de Saúde - CONASS. Guia orientador para o enfrentamento da pandemia Covid-19 na Rede de Atenção à Saúde. Brasília, DF; 2020. [acesso 23 set 2020]. Disponível em: $<$ https://www.conasems.org.br/wpcontent/uploads/2020/05/Instrumento-Orientador-ConassConasems-VERS\%C3\%83O-FINAL-3.pdf $>$

10. Zimmermann P, Curtis N. COVID-19 in children, pregnancy and neonates: a review of epidemiologic and clinical features. Pediatr Infect Dis J. 2020; 39 (6): 469-77.

11. Brodin P. Whyis COVID-19 somild in children? Acta Paediatr. 2020; 109 (6): 1082-3.

12. Wu Q, Xing Y, Shi L, Li W, Gao Y, Pan S, Wang Y, Wang W, Xing Q. Coinfection and other clinical characteristics of COVID-19 in children. Pediatrics. 2020; 146 (1): 1-11.

13. Brasil. Ministério da Saúde. Secretaria de Atenção à Saúde. Departamento de Ações Programáticas e Estratégicas. Proteger e cuidar da saúde de adolescentes na atenção básica. 2 ed. Brasília, DF; 2018. [acesso 26 nov 2020] Disponível em: http://bvsms.saude.gov.br/bvs/publicacoes/proteger_cuidar_adolescentes_atencao_basica_2ed.pd

Received on September 29, 2020

Approved on November 30, 2020
14. Governo do Estado do Ceará [homepage]. IntegraSUS transparência da saúde do Ceará. [acesso 23 set 2020]. Disponível em: https://integrasus.saude.ce.gov.br/.

15. Barros AJD; Hirakata VN. Alternatives for logistic regression in cross-sectional studies: an empirical comparison of models that directly estimate the prevalence ratio. BMC Med Res Methodol. 2003; 3 (1): 21.

16. Götzinger F, Santiago-García B, Noguera-Julián A, Lanaspa M, Lancella L, Carducci FIC, et al. COVID-19 in children and adolescents in Europe: a multinational, multicentre cohort study. Lancet. 2020; 4: 653-61.

17. Oualha M, Bendavid M, Berteloot L, Corsia A, Lesage F, Vedrenne M. Severeand fatal forms of COVID-19 in children. Arch Pédiatrie. 2020; 27: 235-8.

18. Wu Z, McGoogan JM. Characteristics of and Important Lessons from the Coronavirus Disease 2019 (COVID-19) Outbreak in China: Summaryof a Reportof 72314 Cases from the Chinese Center for Disease Control and Prevention. JAMA - J Am Med Assoc. 2020; 323 (13): 1239-42. 